\title{
The Pedagogical, Linguistic, and Logistical Problems of Teaching Russian to the Local Soviet Central Asians
}

This study is an assessment of the theories and practices of teaching Russian to the local (indigenous) Turkic and Iranian speaking peoples of Soviet Central Asia. More specifically, it is a description of the processes by which the programs of teaching Russian as a second language (TRSL) are implemented in the classrooms of Central Asia. An investigation of methodologies in TRSL, qualifications of teachers, and some of the characteristics of the target groupthe young Central Asians-sheds light on the factors accelerating or inhibiting the acquisition of Russian as a second language in this part of the USSR.

Language acquisition, like other forms of learning, is influenced by many factors, not all of them present in the school environment. ${ }^{1}$ The present study assumes that schooling is important in the acquisition of a second language, as an apparent "best" alternative to nonformal types of education such as on-thejob training, but it also reveals that the "best" alternative alone does not always lead to the best results. The discovery and the development of supportive economic, social, cultural, and political institutions are necessary as well. One factor signifying the importance of the school is the fact that the demand for

1. Recent studies by the International Association for the Evaluation of Educational Achievement (IEA) have identified about 800 independent variables impacting on the achievement of a single child. Dependent achievement variables have been identified to correlate with "inputs" such as teachers, pupils' characteristics, the structure of the school, classroom pedagogical practices, and variables associated with background. For a good reference to the related works of IEA and topics relevant to cognitive development of children see the special issue of Comparative Education Review, 18, no. 2 (June 1974), devoted entirely to the discussion of international studies on educational achievement. The USSR, unfortunately, did not participate in this project.

Financial support of the American Association for the Advancement of Slavic Studies and research assistance of Mr. Sheldon Hutchison is gratefully acknowledged. Some of the materials used in this article were obtained during a visit to the Soviet Union financed by the Center for International Comparative Studies of the University of Illinois at Urbana-Champaign. I am grateful to the Center and to many Soviet friends for their help and hospitality. Neither they nor institutions mentioned are responsible for the content of this article. All of the translations from the non-Russian languages and some from the Russian language are mine. Transliteration keys detailed in Edward Allworth's edition of Nationalities of the Soviet East: Publications and Writing Systems (New York, 1971) have been used for the indigenous Soviet Central Asian languages throughout this work. 
language learning like the demand for other forms of learning is derived. The more one learns or gets educated the more one wants to go on learning. This demand becomes more intense when various reward packages are attached by the society to various levels of education and different types of competency credentials. For learners, theoretically, successive levels of education provide greater numbers of alternatives. Language learning, especially learning of Russian for Central Asians, is analogous in terms of its effect, for it provides an individual with options among alternative futures. One of the most important of these options seems to be social and spatial mobility in the USSR. In Central Asia, learning some Russian permits one to move into the urban centers of the area where opportunities to move up the occupational structure and to augment the level of linguistic competence are much richer than in the rural areas. In spite of the advantages, however, the proportion of Central Asians who are fluent in Russian lags behind the average for all other non-Russians (see the census data in Brian Silver's article in this symposium). Although it is difficult to isolate all the factors which may have contributed to this lag, some of them are discussed here and in the two preceding essays. Other factors may be anchored in the cultures, traditions, and social-psychological make-up of the people.

Soviet Central Asia is composed of the union republics of Tadzhikistan, Uzbekistan, Turkmenistan, and Kirghizia. In 1970, the area was inhabited by about twenty million people scattered over 1.23 million square kilometers. ${ }^{2}$ The area has had experiences with numerous alphabets prior to the introduction of the Cyrillic script in the late 1930s, ${ }^{3}$ and the most important of these seem to have been Arabic and Latin. The Arabic alphabet came into the area with the Iran-Islamic armies in the eighth century, and it continued as a means of communication and instruction in the schools until the latter half of the 1920s, when it was replaced by the Latin alphabet. In 1938, the Cyrillic alphabet was introduced in Central Asia, and it replaced the Latin alphabet almost totally in all printed material by the early 1940s. Also, on March 13, 1938, by official decree, the teaching of the Russian language became compulsory in the schools of non-Russian people, including those residing in Central Asia. ${ }^{4}$

By the middle of 1938 almost all of the Central Asian republics had adopted similar decrees on the compulsory teaching of the Russian language. The task of preparing the necessary teachers fell to the Commissariat of Edu-

2. TsSU, Itogi vsesoiuznoi perepisi naseleniia 1970 goda, vol. 1: Chislennost' naseleniia SSR, soiuznykh $i$ avtonomnykh respublik, kraev i oblastei (Moscow, 1972), p. 7 (hereafter cited as Itogi, 1970); and p. 11 of each volume of the 1959 All-Union Census devoted to each of the above republics.

3. H. A. R. Gibb, The Arab Conquests in Central Asia (London, 1928); N. A. Baskakov, "O sovremennom sostoianii $\mathrm{i}$ dal'neishem sovershenstvovanii alfavita dlia tiurkskikh iazykov narodov SSSR," Voprosy iazykoznaniia, 1967, no. 5, pp. 33-46.

4. M. R. Shukurov, Revolyutsiyai Madani dar Tojikiston (Stalinabad, 1957), p. 76. 
cation in each republic, and because such teachers were extremely scarce in Central Asia at that time, the republics were forced to import teachers from the Slavic speaking areas of the USSR. Other republics, but especially the RSFSR, provided numerous Russian teachers for the Central Asian secondary and incomplete secondary schools. In 1938, for example, Tadzhikistan received 368 teachers from the Russian republic. Central Asians, of course, also started massive teacher training programs and, by the end of 1939 , about 5,000 teachers of Russian for grades $2-4$ had been trained in Tadzhikistan alone. ${ }^{5}$

Numerous conferences and meetings to legitimize the conversion to the Cyrillic alphabet and to legitimize and expand the teaching of Russian in Central Asia have taken place over the past thirty-five years. One of the more important of these meetings, the Conference on the Development of Literary Languages, took place in Alma Ata in 1962 and had as its main concern the creation of common lexical stocks for the languages of the USSR. However, as Lewis has pointed out, in actuality the conference was to investigate the relationships of the non-Russian languages to the Russian language. ${ }^{6}$ The result of all these relationships has been a continuous influx of Russian words, often at the expense of local terms, in almost all of the non-Russian languages of the USSR, but the reaction of the indigenous people has been quite varied (as Jonathan Pool notes in his article for this symposium).$^{7}$

The first interrepublic conference on the study of Russian in these Muslim republics took place in Tashkent in August 1965 following the reorganization of the Soviet schools under the provisions of the so-called Khrushchev Reforms. Subsequently, similar conferences have been held to discuss various aspects of teaching Russian as a second language. The result of these conferences has been a significant increase in the number of hours devoted to the Russian language and Russian language related materials in the non-Russian schools. ${ }^{8}$

5. Ibid., p. 76ff. It should be noted that teachers produced in the Central Asian republics at this time were, in general, poorly trained in teaching Russian as a second language (TRSL).

6. E. Glyn Lewis, Linguistics and Second Language Pedagogy: A Theoretical Study (The Hague: Mouton, 1974), p. 58.

7. A Tadzhik rationale for this influx of Russian words is offered by V. Asrori, a faculty member of the Philology Department of Tadzhik State University in his "Zabondoni fazilati odamist," in Tojikistoni Soveti (hereafter cited as TS), March 6, 1966, p. 4.

8. Rahbari Donish (August-September 1930), Arabic script, p. 13; Beatrice King, Changing Man: The Education System of the USSR (London: Victor Gollancz Ltd., 1936), pp. 312-14; Uzbek SSR, Narodnyi Kommissariat Prosveshcheniia, Instruktsiia o provedenii soveshcheniia uchitelei $v$ avguste 1939 (Tashkent: Narkompros, 1939), pp. 13-16; "Organization of Education," Central Asian Reviezv, 9, no. 1 (1961): 27; "Planii ta'limi," Maorif va Madaniyat (hereafter cited as $M v M$ ), May 19, 1970, p. 4; $M v M$, June 7,1975 , p. 4 ; "Ozbekiston bashlanghich sakkiz yillik va orta umumii ta"lim maktablarining 1974/75 ūgur yili uchun, 'oquvplani,' ozbek tilida uqitiladigan maktablar uchun," MvM, September 10, 1974, p. 4. 
On March 28, 1968, a conference was held for teachers of Russian in Dushanbe, Tadzhikistan. At this conference, the role of the Russian language in "bringing together" (Nazdikshavi, sblizhenie) the socialist nations was discussed. The meeting was addressed by one of the secretaries of the Central Committee of the Communist Party of Tadzhikistan, I. Rahimova, who declared that the learning of Russian by non-Russian peoples was the "greatest weapon at the hand of our party in the process of unification of all Soviet People." Other conferences on various pedagogical aspects of TRSL have been held over the past decade at both republic and federal levels. ${ }^{10}$ In all of these conferences and in related material appearing in the Soviet press and the electronic media there seems to be one consistent, recurrent theme: glorification of the Russian language and rationalization of its dominant position in government and commerce.

The thesis of the CC of the CPSU and the Council of Ministers of the USSR, Regarding the Strengthening of the Relationship of School and Life and for the Further Development of the System of Public Education in the USSR, which was published November 16, 1958, puts forward the official view. The nineteenth clause reads:

In the Soviet schools instruction is conducted in the native language. This is one of the more important achievements of the Leninist national policy. At the same time in the union and autonomous republics is also studied the Russian language which is a great means of international communication, of strengthening of friendship among the peoples of the USSR and of introducing them to the treasures of Russian and world cultures. ${ }^{11}$

The importance of studying the Russian language is made very clear by this statement. It is not only a "window" to the outside world, but also the vehicle of international communication and friendship among people. Few would want to undermine such an arrangement by opting not to study Russian. There is no doubt, also, that, at present, without knowledge of the Russian language, it is impossible to become a Soviet leader. Thus, Russian is a prerequisite for upward social, political, and economic mobility.

There are still other stimuli for learning Russian. For example, "Russian language is the most important means in the making of a Communist; one can learn ethical behavior, patriotism, and so forth . . . reading Gorky, Turgenev, and ... stories by Gogol makes one selfless in defense of the motherland."12 Kanimetrov, the Kirghiz minister of education, claims that those who learn

9. "Mashvarati muallimoni zaboni rusi," $M v M$, March 30,1968 , p. 3.

10. Iu. Askarov, "Zaboni duiumi modarii mo," MvM, December 20, 1969, p. 2.

11. Quoted in John Kolasky, Language Policy: Education in Soviet Ukraine (Toronto: Peter Martin, 1968), p. 26.

12. A. F. Zhuravleya, "Roli zabon va adabiyoti rus dar tarbiiai kommunistii khonandagon," $M v M$, June 4, 1968, p. 4. 
Russian become better students and adjust better in life. ${ }^{13}$ An editorial states that "the children must be prepared to fulfill their duty to the motherland, to study arduously the Russian language, in which are written the regulations, military orders, and instructions in which their comrades and commanders will speak."14 And Asrori writes that Russian "is the language of Lenin, Gorky, the Communist Party, . . . Mayakovsky; it is the language of cosmonauts; it is the language of the country. . . . Moreover, the great literary figures of the Tadzhik literature such as Rudaki, Ibni-Sino, Firdausi, Nosir Khisrav, Umar Khayyom, Sa"di, Hofiz, Jomi, Bedil, and Ahmad Makdum Donish were competent in more than one language."15

Science and technology and cultural development are also areas which emphasize the need for the learning of Russian. For example:

Every day new machinery comes into Tadzhikistan. Therefore, the addition of these Russian-International words increases the wealth of our language. Learning of the mother tongue is needed not only for cultural reasons but also because of the fact that creative thinking, intelligence, logical thinking is done effectively through the mother tongue. . . . However, one of the essential criteria in achieving the high cultural level of the Soviet Man is through learning of the language of the great Russian people. It is the Russian language through which we learn about the technical and scientific progress of the world and other human achievements. Nevertheless, one should emphasize that one cannot learn the Russian language without first mastering his own mother tongue. ${ }^{16}$

Further:

Learning Russian makes one moral; it helps one to grasp scientific and technical knowledge; it brings people together; increases one's social and political mobility; leads to the development of the socialist person; leads to the economic development of the country; leads to political stability; leads to the development of culture ; increases friendship among the large and small peoples; it gives needed ideological and political content to the development of the young; it reflects the level of knowledge and the spirit of internationalism and socialism of an individual. ${ }^{17}$

13. "Zaboni rusi-zaboni man, zaboni mo," TS, November 10, 1972, p. 4.

14. Editorial, "Vyshe uroven' vospitatel'noi raboty," in Russkii iazyk i literatura v azerbaidzhanskoi shkole, 1973, no. 8, p. 5.

15. V. Asrori, "Zabondoni fazilati odamist," p. 4.

16. R. Yusofbekov (former Tadzhik minister of education and present deputy prime minister of Tadzhikistan), speech on the occasion of the Conference of the Teachers of Tadzhik Language and Literature, "Talaboti zamon va tadbirhoi minba"d behtar namudani ta"limi zabon va adabiyoti Tojik," $M v M$, January 10, 1974, pp. 2-3.

17. L. V. Uspenskaia, "Roli zaboni modari dar omuzishi zaboni rusi," $M v M$, April 5,1975 , p. 2. For an example of the local decision-makers' attitudes, see Sh. R. Rashidov (candidate member, Politburo of the CC of the CPSU and first secretary of the Uzbek SSR Communist Party), "Zaboni rusi-zaboni robita va hamkorii millatho va khelqhoi ittifoqqi soveti," MvM, November 27, 1975, pp. 1-3. 
All of these qualities are, of course, empirical questions that have not been validated. That is, many authors (both indigenous and Europeans) seem to have simple faith in the power of the Russian language to cause behavioral changes in individuals. Some of this rhetoric reminds one of General K. P. Von Kaufman, when he was the governor general of Russian Turkestan, and of the preachings of V. I. Il'minskii. Both saw nineteenth-century Russian culture, including the Orthodox church, as a reference culture that would draw non-Russians to it and thereby elevate their cultural levels. ${ }^{18}$

Can Russian become the language of the peoples of the USSR ? To answer this question one has to look carefully at Soviet linguistic policies in which some of the above statements are anchored and at the programs and plans which have been designed for their implementation. For example:

The ultimate aim of Soviet social and linguistic policy was stated by Stalin as early as the XVIth Congress-"the fusion of nations, languages and cultures" and this ultimate objective has never been abandoned or even modified except to the extent that what was originally set out as a declaration of intent is now progressively articulated as a maturing programme. ${ }^{19}$

Statements by Lenin and Stalin do not leave any doubt about the virtues of the centralization ${ }^{20}$ and suitability, if not the superiority, of the Russian language as the means of communication and instruction. ${ }^{21}$ But the idea of merging of nations into a single socialist people, of sharing one single language, among many other things-which was for decades the overt linguistic policy of the USSR - has now been somewhat modified. The element of coercion has been replaced by sets of apparently much superior stimuli, some of which were listed above. These new stimuli are products of the present high levels of economic, educational, political, and social development of the USSR, and they intensify the pressure for the acceptance of Russian as the language of the Soviet peoples to a degree unknown in the history of the USSR.

It is a push-pull situation. One is pushed to learn Russian by one's peers, mass media, and the Soviet cultural and political institutions. And one is also pulled by unparalleled rewards in the form of spatial and social mobility. Moreover, a positive response to both of these forces is supposedly possible without

18. Richard Pierce, Russian Central Asia, 1867-1917 (Berkeley and Los Angeles: University of California Press, 1960), passim.

19. E. Glyn Lewis, Multilingualism in the Soviet Union (The Hague: Mouton, 1972), p. 54.

20. Lewis, Multilingualism, p. 181.

21. V. I. Lenin, "Is it necessary to have an official government language?," Osorho, Tadzhik edition, vol. 20, pp. 61-62, quoted by O. Sh. Shukurov, "Zaboni Lenini," MvM, March 5, 1968, p. 2. 
sacrificing the allegiance of the members of one's community, or one's language. 22

It is also necessary to realize that there probably have been very few languages other than Russian on behalf of which such intensive propaganda has been orchestrated. Printed and electronic media, scholarly journals, and books have had the cause of the Russian language as a topic of discussion in recent years. In fact, pressure for learning the Russian language is encountered wherever one goes in Soviet Central Asia. One cannot work effectively in any of the urban centers of this area without some knowledge of the Russian language. Almost all street signs and those describing means of transportation are in Russian. Television and radio programs seem to be dominated by the Russian language. Sampling of random weeks of television programing (in February 1974 and in August 1975) in Dushanbe revealed that the material about and in the Russian language amounted to more than 70 percent of total broadcasting time. ${ }^{23}$ Also, a random selection of five days of radio programing revealed that about 50 percent of the programs were in the Russian language. ${ }^{24}$ (Of course, there is always a possibility that some people will tune in to radio programs other than those originating in the USSR.)

In spite of all these efforts, Central Asians still lag behind the rest of the non-Russian population of the USSR in the acquisition of Russian. This fact has not been lost on Soviet authorities, who have been complaining recently about the poor quality of the teaching of Russian as a second language (TRSL) in Central Asia. ${ }^{25}$ As early as 1950, the most common cases of failure in schools in Mordovia, Bashkeria, and Tataristan at the elementary level were failures in the Russian language. ${ }^{26}$ Today, the very high rate of failure in Russian language study is found among non-Slavic children elsewhere in the USSR. In fact, the problem of failure in Russian constitutes one of the major educational problens of the Soviet Union.

From the standpoint of Soviet educators, there are several problems which seem to have contributed to student failures and which have persisted in TRSL

22. Sh. R. Rashidov, "Zaboni rusi-zaboni robita va hamkorii millatho va khalqhoi ittifoqqi soveti," $M v M$, November 27, 1975, pp. 1-3; see Brian Silver's contribution to this symposium, "Bilingualism and Maintenance of the Mother Tongue in Soviet Central Asia," for a thorough statistical analysis of the language situation in Central Asia.

23. $M v M$, February 16, 1975, p. 4; MvM, August 2, 1975, p. 4; TS, November 7, 1975, p. 4. See also Zev Katz, R. Rogers, and F. Harned, eds., Handbook of Major Soviet Nationalities (New York: The Free Press, 1975), "Media" section, for a discussion of Central Asian nationalities; M. Mobin Shorish, "Soviet Central Asia: A Brief Personal Report," Cahiers du Monde Russe et Soviétique, Spring 1976.

24. See Komsomoli Tojikiston, February 7, 1973, p. 4; January 20, 1974, p. 4; TS, August 3, 1975, p. 4 ; August 5, 1975, p. 4; November 18, 1975, p. 4. (1975).

25. J. F. Besemeres, "Population Politics in the USSR," Soviet Union, 2, nos. 1-2

26. A. M. Valitov, "Nasushchnye zadachi pervonachal'nogo obucheniia russkomu iazyku v natsional'noi shkole," Russkii iasyk v shkole, 1952, no. 2, p. 67. 
in Central Asia over several decades. These perennial problems fall into two general categories: students and the problems associated with the linguistics and pedagogy of second language learning; and teachers of Russian, their training and the logistics required for Russian language teaching.

Central Asian students, when learning Russian, experience great orthographic and pronunciation problems. These orthographic mistakes, associated with incorrect pronunciation, suggest that teachers should pay close attention to the students' mother tongue to see if some of the problems of pronunciation could lie there. ${ }^{27}$ One of the most important matters which has concerned educators over the years has been the very low lexical stocks of the non-Slavic children, who often memorize words without being able even to perceive their meanings because the words are absent from their own languages. ${ }^{28}$ The problem of pronunciation, orthographic mistakes, grammatical errors, and inability to distinguish between consonants and vowels all lend themselves to poor syntax for Central Asian children, ${ }^{29}$ and the problem is most apparent among rural children, who are unable to speak and write a simple Russian sentence after ten years of in-class instruction. ${ }^{30}$

There are aspects of TRSL which by necessity differ from one region to another. Nevertheless, for many years a standardized method of TRSL was prescribed from the central government for non-Russian students. In general, the phonemic problem is one of the most persistent for almost all of the nonSlavic nationalities in Central Asia. It was discovered that Uzbek children are unable to distinguish between the sounds of two or more letters. The most problematic pairs for children in grades 2-4 in Uzbek schools were:

$$
b-v, p-f, o-u, e-i \text {, and } y-i . .^{31}
$$

27. V. N. Kliueva, "Ustnyi kurs v programmakh po russkomu iazyku dlia nerusskikh shkol," Russkii iazyk v shkole, 1952, no. 2, p. 77.

28. A. Mokhov, "O razgovornykh urokakh," Russkii iazyk v shkole, 1952, no. 3, pp. 63-64; see also in the same issue, I. A. Kissen, "O razgovornykh urokakh bez chteniia i pis'ma," pp. 61-62; F. V. Tarzimanov, "O razgovornykh urokakh $v$ pervom klasse $v$ nerusskoi shkole," pp. 65-66; and A. F. Boitsova and L. A. Varkovitskaia, "Pochemu neobkhodim predvaritel'nyi ustnyi kurs russkogo iazyka," pp. 66-69.

29. "Tadzhikistan," Central Asian Review, 1, no. 1 (1953):43-44. The same criticism is made for Kazakhstan in Central Asian Review (hereafter cited as $C A R$ ), 2, no. 2 (1954) :187-89.

30. CAR, 5, no. 1 (1957):38; also Kommunist Tadzhikistana, April 5, 1956; Sovetskaia.Kirgiziia, April 18, 1956; W. K. Medlin, William M. Cave, and Finley Carpenter, Education and Development in Central Asia: A Case Study on Social Change in Usbekistan (Leiden: E. J. Brill, 1971), p. 105.

31. N. A. Piantina, "Rabota nad oshibkami na urokakh russkogo iazyka v II-IV klassakh uzbekskoi shkoly," in I. M. Dmitrieva, ed., Voprosy metodiki prepodavaniia russkogo iazyka v uzbekskoi shkole: Sbornik statei (Tashkent: "Uchitel'," 1974), pp. 33-39. 
They also fail to appreciate the difference between the soft sign and the hard sign. For students in the Tadzhik schools the most difficult sounds were:

$$
e-i a, i u-i o, y-i, q, c h, j \text {, and } f .^{32}
$$

The difficulties which Tadzhik students experience with the above sounds are manifested in pronunciation of words and in orthography. Children are most confused in distinguishing orally and aurally between $y$ and $i^{33}$ as in:

$$
\begin{aligned}
& \text { byl-bil } \\
& \text { myl-mil } \\
& \text { pyl-pil. }
\end{aligned}
$$

Also, problems of lack of discrimination on the part of Tadzhik children arise regarding:

$$
\begin{array}{ll}
\text { est-est' } & \text { úgol-ugol' } \\
\text { shar-zhar' } & \text { el-el' } \\
\text { mel-mel' } & \text { pyl-pyl' } \\
\text { semia-sem'ia } & \text { polet-pol'et }
\end{array}
$$

and so forth. ${ }^{34}$ The problems of other Central Asian children are similar, though not identical (because of variations in their mother tongues), to those of Uzbeks and Tadzhiks. ${ }^{35}$

Central Asian students are also unable to distinguish between simple and complex sentences, that is, sentences that do not follow clear subject-predicate forms are hard for them to construct. They are generally very rigid in their usage of conjunctive words in subordinate clauses. For example, they make the mistake of thinking that all clauses using kogda are temporal and that all clauses using $k a k$ indicate form of action or comparison. ${ }^{36}$ In addition, non-

32. A. Ëshonjonov, M. Shukurov, and M. Rahmonov, Metodikai ta"limi zaboni tojiki dar maktabi ibtedoi, (kitobi darsi baroi omyzishgohhoi pedagogi) (Dushanbe: Nashriyoti Irfon, 1964), pp. 42-47.

33. E. V. Zakharova, "Tvorcheskii diktant $\mathrm{v}$ shkole s tadzhikskim iazykom obucheniia" in I. M. Dmitrieva, ed., Voprosy metodiki prepodavaniia russkogo iazyka v uzbekskoi shkole, pp. 47-48.

34. Ibid.

35. G. I. Popova, "Rabota nad orfografiei v protsesse usvoeniia obshchei leksiki dlia russkogo i azerbaidzhanskogo iazykov," Russkii iazyk i literatura $v$ azerbaidzhanskoi shkole; 1973 , no. 2, p. 26.

36. S. B. Babaev, "O prichinakh nedochetov russkoi rechi uchashchikhsia karakalpakskoi shkoly," Russkii iazyk v natsional'noi shkole, no. 1 (January-February 1973), pp. 70-72. 
Slavic children experience difficulty with Russian verb aspect, ${ }^{37}$ hard and soft consonants, ${ }^{38}$ and Russian words in non-Russian syntax..$^{38}$

One of the most controversial and conflict-ridden aspects of the TRSL program in Central Asia has been the role and the place of the mother tongue in the process of learning Russian. In the context of Soviet linguistic policy, the politics of language has often overshadowed valid pedagogical and linguistic discussions of the subject. The non-Slavic Central Asians frequently have blamed the Russian teachers' lack of knowledge of the students' mother tongues as one of the most important factors inhibiting the successful teaching of Russian, thereby causing the failure of Central Asian children to score higher in Russian language classes. ${ }^{40}$ The following is a Kazakh's reaction:

Ignorance of the Kazakh language on the part of the teacher reacts unfavorably on his teaching. The teacher often wastes much time and effort explaining some words or constructions of sentences through the medium of Russian, which is not fully understood [by the students] by the end of his discussion. ${ }^{41}$

The argument against the mother tongue as the medium in TRSL takes place on apparent social-psychological and linguistic grounds. Simply stated, some Soviet educators think that, in isolating the learner from the impact of the mother tongue and developing a "Russian only" environment, one can increase the rate of acquisition of the Russian language. Dzhafarzoda, in a study of bilingualism (Russian-Azeri), found higher frequencies of bilinguals in the urban and workers' villages than places which could not afford the type of infrastructures (media, other means of communication, factories, and so forth) conducive to bilingualism. ${ }^{42}$ These debates do not take into account the function

37. L. Z. Sharikova, "K voprosu izucheniia kategorii vida $v$ tiurkoiazychnoi shkole," Voprosy teorii $i$ metodiki izucheniia russkogo iazyka (glagol) (Kazan': Ministerstvo prosveshcheniia RSFSR, Kazanskii Gosudarstvennyi i pedagogicheskii Institut, 1971), pp. 3-26. See also, Editorial, "Sifati ta"limro dar guruhhoi makhsus baland bardorem," $M v M$, March 5, 1968, p. 1.

38. A. R. Makhmudov, "Tverdye i miagkie soglasnye russkogo iazyka," Russkii iazyk $i$ literatura $v$ azerbaidzhanskoi shkole, 1973, no. 11, pp. 49-56.

39. B. Niyozmuhammadov, Zabonshinosii tojik (Dushanbe: Donish, 1970) especially pp. 365-83. See also issues of the specialized journals cited in this paper.

40. S. M. Makhmudova, "Iz opyta ispol'zovaniia pri izuchenii russkogo glagola v uzbekskoi shkole," in Voprosy metodiki prepodavaniia russkogo iazyka $v$ uzbekskoi shkole, pp. 6-20.

41. Kazakhstanskaia pravda, March 27, 1956, quoted in $C A R$, 5, no. 1 (1957):39.

42. A. M. Dzhafarzoda, "Kratkaia lingvisticheskaia kharakteristika azerbaidzhanskogo-russkogo dvuiazychiia," Russkii iazyk i literatura v azerbaidzhanskoi shkole, 1973, no. 4, pp. 82-87. For a detailed study of Soviet efforts in bilingualism see Diana E. Bartley, Soviet Approaches to Bilingual Education (Philadelphia, 1971). See also K. S. Abilov, "Interferentsiia navykov pis'ma $v$ protsesse obucheniia russkoi gramote $v$ uchashchikhsia azerbaidzhanskikh shkol," Russkii iazyk i literatura $v$ azerbaidzhanskoi shkole, 1973, no. 6, pp. 81-87; and A. R. Makhmudov, "Tverdye i miagkie soglasnye russkogo iazyka," ibid., 1973, no. 11, pp. 49-56. 
of the mother tongue in the overall educative process of the young. Instead, a great many Russians and some non-Russian scholars and politicians insist on a program of TRSL which makes Russian the "second mother tongue" of the non-Russian people. Apparently, the term "second mother tongue" is meant to imply the ability of the learner to think in Russian as well as in his mother tongue. ${ }^{43}$

Many writers insist on using Russian as a medium of TRSL. "The present method of teaching Russian in national schools requires limitation, as much as possible, of the influence of the mother tongue." 44 Such statements are often made without clear and adequate substantiation, and too many of them are documented by appealing to authorities who are either unknown to the reader, or who are not authorities in the area of specialization. Appeals to people like Ibrahim Altynsarin (1841-89, Kazakh educator, translator, and a colleague of tsarist missionary Il'minskii), Marx, Engels, and other scholars, whose interests in linguistics and second language teaching have been tangential, is an all too common strategy.

This does not mean, however, that serious discussions of this topic are not taking place at other levels in the USSR's academic circles. The question of language policy and problems in linguistics have been discussed in this part of the world with much more intensity and at a higher level of sophistication, and over a much longer period, than in most countries in the world. What has been discussed in this paper, up to this point, are the pedagogical problems of second language teaching from the standpoint of the practitioners in the classrooms of the Soviet Union-the teachers, the inspectors, the language specialists, and other educators. ${ }^{45}$ These people have been taking widely divergent views in discussing the role of the mother tongue in TRSL. Generally, the Russians have advocated no role for the mother tongue, and the local Central Asians have advocated a great role for the mother tongue. Frequently, these views are expressed without any linguistic or pedagogical justification, even though, from a pedagogical point of view, the positive role of the mother tongue in children's cognitive and affective development is unassailable.

Language specialists, at a UNESCO meeting, agreed that it was essential for learners to start schooling in their own mother tongue, in order to minimize both the problem of conceptualization and the break between the home and the

43. T. M. Radzhabova, "Nekotorye voprosy prepodavaniia russkogo iazyka $\mathbf{v}$ nachal'nykh klassakh azerbaidzhanskikh shkol," Russkii iazyk $i$ literatura $v$ azerbaidzhanskoi shkole, 1973, no. 2, pp. 3-11.

44. L. V. Uspenskaia, "Roli zaboni modari dar omuzishi zaboni rusi," p. 2.

45. Apparently, in the Soviet Union, the linguists and second language teachers do not often communicate with each other. See E. Glyn Lewis, Linguistics and Second Language Pedagogy: A Theoretical Study, especially pp. 19-30, for a Westerner's complaint; see also the editorial "Sifati Ta"limro dar guruhhoi makhsus bland bardorem," $M v M$, March 5, 1968, p. 1, for a Soviet complaint. 
school. The specialists also agreed that teachers of the second language should know the mother tongue of the pupils, and that the transfer to the second language should be postponed as long as possible. ${ }^{46} \mathrm{~S}$. M. Makhmudova, an Uzbek educator, relies on comparative grammar as one of the best methods in TRSL. In this method the use of the mother tongue becomes essential. The economy embedded in comparative grammar makes it an attractive method. Since many children know about some aspects of the grammar of their language before coming to school, it is not necessary to give lengthy definitions or explanations of those aspects which the two languages have in common. ${ }^{\mathbf{4 7}}$

According to Makhmudova, the contrastive linguistics approach (which by necessity relies on teachers' bilingual ability) includes the comparison of the phonetic and grammatical phenomena of Russian and the native languages, and translations from Russian to the native language and from the native language to Russian. In this undertaking, materials can be grouped according to: (a) phenomena similar or identical in both languages, which need not be time consuming; (b) phenomena characteristic of both languages, but not identical, which need explanation and clarification by the teacher because of native language interference; (c) phenomena particular to Russian and absent from the students' native language, which makes this area completely new to the learners and free from interference by the mother tongue. The learners' experiences in learning are relatively (to [b] above) less ambiguous. ${ }^{48}$

The non-Russian educators of Central Asia have also been taking a leaf from the Russian educators' book in their defense of the mother tongue and the pedagogical value assigned to it. They have turned some of the arguments advanced by Russian writers for TRSL around to describe the usefulness of the mother tongue, not only as a facilitator in TRSL, but also, in its own merits, as conducive to learning. ${ }^{49}$ The importance of the native languages in the flowering of human culture and civilization is mentioned over and over by these non-Russian writers. For example:

There is evidence pointing to the fact that in schools the importance and the need for learning Tadzhik language is not emphasized at all. One must increase the enthusiasm of students in a language in which Rudaki [Abū Abdullāh Ja"far b. Muhammad Rūdakī Samarqandi, d. 940], Khayyom [Omar Khayyām, 1022-1122], Sino [Abū Alī Ibni Sinnā, Avicenna, 980-1037], Firdavsi [Abulqāsim Firdavsì d. circa 1020 or

46. "The Use of Vernacular Languages in Education: The Report of the UNESCO Meeting of Specialists, 1951," in J. Fishman, ed., Readings in the Sociology of Language (The Hague: Mouton, 1968), pp. 688-715.

47. S. M. Makhmudova, "Iz opyta ispol'zovaniia sopostavlenii pri izuchenii russkogo glagola $v$ uzbekskoi shkole," pp. 6-20.

48. Ibid., p. 10 ; see also M. Abdulloeva, "Zaboni rusiro boz behtar omuzem," Zanoni tojikiston, June 1971, p. 18.

49. V. Asrori, "Zabondoni fazilati odamist," p. 4. 
1025], Sa"di [Abū Abdullāh Musharrifuddīn d. 1292], Hofiz [Shamsuddin Muhammad d. 1320], Donish [Ahmad Makhdūm, 1827-97], and Ayni [Aini, Sadriddin, 1878-1954] have written eternal works. ${ }^{50}$

Central Asians also appeal to the same authorities as do the Russians in advocating the teaching of the mother tongue:

Marxist-Leninist psychology and pedagogical methodologies testify to the validity and fruitfulness of learning the mother tongue concomitantly with a new language. Karl Marx certified that a new language should be learned in connection with one's mother tongue ... our experience in training Russian language teachers (the first in the USSR) proved that the Russian teachers who know the mother tongue of the pupil have been the most productive. . . . ${ }^{51}$

There are, in general, two types of teachers of Russian in Central Asianative Russian speakers and non-Russian teachers. In the 1974/75 academic year, there were 4,648 Russian language teachers in the non-Russian schools of the Tadzhik SSR alone. ${ }^{62}$ This is more than double the number of Russian teachers in the republic in $1967 . .^{53}$ Many of the native Russian speakers and other Russian language teachers (mostly other Slavs) have come from areas outside Central Asia. A great many of them come from RSFSR and some from the other two Slavic republics, the Ukraine and Belorussia. In the 1973-75 period about 400 teachers of Russian language with secondary specialized or higher education were imported from the Ukraine and Belorussia into Tadzhikistan alone. ${ }^{54}$ In addition to these fully trained Russian teachers, many future Russian teachers (graduates of pedagogical institutes of Slavic speaking republics) spend their student teaching assignments in Central Asia. In 1971 there were about 700 student teachers in Tadzhikistan. ${ }^{55}$ Almost all of the Russian teachers coming from outside of Central Asia settle in the urban centers of these republics. Since more than 80 percent ( 87 percent in Tadzhikistan) of the schools of Central Asia are in rural areas, ${ }^{66}$ a great many schools go without Russian teachers.

50. S. Ma"rufova, "Rohhoi takmili ta"lim," MvM, August 20, 1968, p. 21.

51. Gh. Ghaniev (docent, Department of Languages, Institute of Agriculture, Tadzhik SSR), "Ba"zi mas"alahoi ta"limi zaboni rusi," $T S$, January 26, 1971, p. 4; see also Gh. Ghaniev, "Ba"zi mas"alahoi omukhtani zaboni rusi," $M v M$, June 25, 1970, p. 2. Numerous works prepared by the local writers stress the virtues of not only teaching the mother tongue to the local children but also of teaching local languages to the Russian students. See the entire issue of $M v M$ of January $10,1974$.

52. R. Dodoboev (minister of education, Tadzhik SSR), "Vaz"iyati ta"limi zaboni rusi va tadbirhoi behtar kardani on," MvM, April 5, 1975, pp. 1-2.

53. B. Tojieva, "Ta"limi zaboni rusi dor tojikiston," MvM, January 16, 1968, p. 1.

54. Dodoboev, "Vaz"iyati ta"limi ...," pp. 1-2.

55. Editorial, "Ta"limi zaboni khalgi buzurg," $M v M$, November 23, 1971, p. 1.

56. Editorial, "Bol'she vnimaniia $\mathrm{v}$ sel'skoi shkole," Russkii iazyk $i$ literatura $v$ 
The effectiveness of both rural (generally non-Slavic) and Slavic Russian teachers in TRSL constitutes, according to most observers, the Achilles heel of the Russian language program in Central Asia. Both of these groups suffer some degree of ineffectiveness. The Slavic speaking teachers, by virtue of their ignorance of the local languages and cultures, and a poor grasp of TRSL methodology, cannot teach productively. On the other hand, the non-Russian teachers, trained in Central Asian educational institutions, have poor training overall. ${ }^{57}$

As previously noted, most Slavic speaking Russian teachers stay in the cities of Central Asia where the infrastructure is not too different from the cities of their home regions. Most local Central Asian graduates of teacher training institutes also prefer to stay in the urban centers. Therefore, the scarcity of qualified Russian teachers in the rural areas of Central Asia remains unchanged. As a result, in the early 1960s, branches of the pedagogical institutes were established which specialize only in the training of Russian teachers for rural non-Russian schools. Further, students of these special branches are drawn exclusively from rural Central Asia and from Central Asian national minorities. Upon graduation, these "special groups" (Guruhoi Makhsus), as they are called, are sent into the districts where they were born to teach Russian to their relatives. ${ }^{58}$ Apparently, however, the quality of training in these branches is very low. Students are, of course, graduates of secondary and elementary rural schools where knowledge of the Russian language is at a very low level.

Poor lesson plans and poor understanding of the systematization of curricula material according to age of students augments the list of problems in TRSL in Central Asia. Each practitioner in the classroom and others who are concerned with the program are encouraged by officials to innovate methods in TRSL. As a result, a hodgepodge of approaches for TRSL are used in the classrooms and pedagogical institutes of the Central Asian republics.

The teaching of Russian as a second language in Central Asia, aside from ideological and political contradictions noted earlier, is marked by other difficulties peculiar to second language pedagogy. First, teaching a language is different from teaching other subjects. As Cozden has observed, "language poses multiple problems for education because it is both curriculum content and learning environment, both the object of knowledge, and a medium through which other knowledge is acquired." ${ }^{59}$ Second, the teaching of a particular second language, Russian in this case, should not be standardized for all stu-

azerbaidzhanskoi shkole, 1973 , no. 12, p. 3 ; B. Khudoidodov, "Ba"ze mas"alahoi ta"limii zabon va adabiyoti rus dar maktabhoi tojiki," MvM, March 20, 1975, p. 2.

57. Editorial, "Ta"limi zaboni rusi dar maktabho," TS, April 2, 1968, p. 1.

58. "The Second Mother Tongue," CAR, 13, no. 4 (1965):310-22.

59. Courtney B. Cozden, "Problems for Education: Language as a Curriculum Content and Learning Environment," Daedalus, 102, no. 3 (Summer 1973):135. 
dents, whose mother tongues differ not only linguistically and in terms of concept from the second language being taught, but also from each other's. TRSL in Central Asia suffers from poor understanding of both of these phenomena.

The problem of the curricula content for Russian teachers in non-Russian schools is a case which illustrates not only the confusion in TRSL, but also the absence of any theoretical foundation. For example, a program for the "special group" (Uzbeks and Tadzhiks) in the special branch of Leninabad Pedagogical Institute had the following courses: (a) special seminar on outof-class work in Russian language and literature; (b) special practical course on writing and composition; (c) special practical course on development of visual aids; and (d) special course on Russian and Tadzhik literature. A Russian language week was added eventually, during which students were apparently to become imbued with Russian culture. ${ }^{60}$

A professor from the same institute has argued that knowledge of Old Church Slavonic is essential in the training of teachers of Russian, for "without it one cannot claim to know the present Russian language, and the thirty hours devoted to it in the program is extremely inadequate."61 One probably cannot argue against teaching Old Church Slavonic to future linguists, but one can question the wisdom of its inclusion in the curriculum of the "special groups" in the Central Asian pedagogical institutes-the extremely poor preparation of the local students at the time of entrance to higher educational establishments (Vuzy) of Central Asia, and the very poor training that the students receive while enrolled in the pedagogical institutes make it infeasible. On similar pedagogical grounds, one can argue against the inclusion of nineteenth-century Russian classics in the "special group" curricula. ${ }^{62}$

Clearly, the major logistical problem in TRSL in Central Asia has been finding qualified Russian teachers. In general, most teachers of Russian are badly trained; but there are not even enough of these badly trained teachers to satisfy the needs. As a result, many schools, especially those in the rural areas of Central Asia, have no teachers at all, or have teachers initially trained for other subjects such as biology and physics, teaching Russian. ${ }^{63}$ Furthermore, statistics often quoted about the percentage of Russian teachers having

60. T. E. Sevost'ianova, "Khonishi ifodanok-kalidi kom'yobiho," $M v M$, March 5, 1968, p. 2. See also V. V. Karakulakov, "Darborai tayyori kardani muallim," ibid., p. 3.

61. B. M. Rusakova, "Grammatikai ta"rikhii zaboni rusi," MvM, March 5, 1968, p. 31 .

62. B. S. Liubana, "Mashghuliyoti amali," $M v M$, March 5, 1968, p. 4.

63. Editorial, "Ta"limi zaboni khalgi buzurg," $M v M$, November 23, 1971, p. 1. "Teachers who work in the rural areas in addition to two months paid vacation are also given free housing, and are excused from the payment of some of the taxes" (Ahmad Birashk, "Dīdāri az shūravĩ va sukhani chand dar bāra'ī āmūzish va parvarish-i shūravī," part 2 of Paydmi Navin [Tehran, 1975]). 
training in higher educational establishments (70 percent in Tadzhikistan in $1975)^{04}$ have to be evaluated in the light of the poor quality of training given these teachers in the $V u z y$ of Central Asia.

Aside from the chronic shortages of qualified Russian teachers, there are chronic shortages of good instructional materials (among them textbooks) and other supportive facilities (including, perhaps, social and cultural institutions) for TRSL in Central Asia. Over the years very few books have been published on TRSL, and those that have been published are deficient in terms of methodology and pedagogy. ${ }^{65}$ The problem of the poor quality of textbook production continues today. Deficiencies in this area, from the point of view of teachers and students, seem to be poor quality paper, very small print, which makes reading difficult, and poor reproduction of illustrations. The shortage of materials designed for out-of-class reading is especially acute. Because of this scarcity of reading materials and the poor production of the materials which can be obtained by the students, the out-of-class TRSL program in Central Asia, especially in the rural areas, has been a failure ${ }^{68}$ It is interesting to note that almost all textbooks in TRSL are authored by non-Central Asians and that, apparently, the best teachers in the TRSL program are non-Central Asians, judging by the names of teachers who have received "best Russian teacher" awards. ${ }^{67}$

There are probably as many proposals for teaching methods for TRSL in Central Asia as there are teachers. This is partly because the Soviets encourage individual teacher innovations in teaching methods, but idiosyncrasies of particular teachers, composition of the student body in terms of ability, ethnicity, mother tongue, and social class background, and the urban or rural location of the schools are also important factors.

In general, formal education and its language teaching component in the USSR are teacher-centered. Formal language teaching, in particular, requires a transmitter (such as a teacher or a machine) which systematically transmits to the learner new information, in forms of new words, sentences, and aspects of the culture of which the language being taught is a part. The TRSL teachers in Central Asia often have been faulted not only for their poor training in the art of TRSL, but also for their inability to make linkages between the language

64. B. Khudoidodov, "Ba"ze mas"alahoi ta"limi zabon va adabiyoti rus dar maktabhoi tojiki," p. 2.

65. Ibid., p. 1; see also F. L. Rubenshtein, "Iz opyta primeneniia diafil'mov na urokakh russkogo iazyka i literatury v VI klasse uzbekskoi shkoly," in I. M. Dmitrieva, ed., Voprosy metodiki prepodavaniia russkogo iazyka v uzbekskoi shkole: Sbornik statei, pp. 107-14.

66. Ibid.; $C A R, 5$, no. 1 (1957):39-40; and relevant materials from the Central Asian press and personal talks with many students and teachers in Tadzhikistan and Uzbekistan in 1973.

67. Editorial, "Mukofot muborak, omuzgoroni arjmand," MvM, April 6, 1968, p. 1. 
being taught and the political, economic, and ideological dimensions of the Soviet social system. ${ }^{68}$ Apparently, policymakers believe that a good teacher in TRSL is one who, in addition to good academic qualifications, also has a desirable political and ideological orientation. ${ }^{69}$ The empirical evidence on teachers' political orientations in the educative process of the young is sketchy and often contradictory, especially concerning the teachers' role in the process of political socialization of children. ${ }^{70}$ But there is no doubt that a teacher's qualifications and professional commitment are significant in children's achievement. This role is probably most obvious in the teaching of a second language, where the teacher's awareness of stages of cognitive development of children and of the role of social class in the process of acquisition of knowledge and its retention are crucial.

The methodology of TRSL remains basically partisan. The non-Russian Central Asian educators, for the most part, believe in the superiority of comparative grammar (which permits teachers to talk about both languages and requires them to be bilingual). The native Russian teachers and other Slavs interested in the topic insist that increasing and developing the student's vocabulary is the best method for solving the present TRSL problems. This proposal prohibits talking about the languages involved, and has long been favored by the Russians.

The early 1960s witnessed activities on the part of teachers in Central Asia for the implementation of some of Khrushchev's reforms, which in TRSL were vocabulary development, sentence construction, and development of skills on speech narratives. ${ }^{71}$ All of these were to take place with minimal usage of the mother tongue. The purpose of this program was to give seventh and eighth grade students the ability to develop their skills in written and oral Russian. The method was actually the drilling of each word and sentence until it was memorized and pronunciation was perfected. Teachers were also concerned about the development of sets of superior stimuli outside and inside school to motivate children to learn Russian. This method, however, failed to increase the children's (especially rural children's) level of achievement in Russian, and the rate of failure of Central Asian children in Russian language

68. Editorial, "Ta"limi zaboni khalgi buzurg," $M v M$, November 23, 1971, p. 1.

69. Ibid.

70. See, for example, Richard M. Merelman, "The Adolescence of Political Socialization," Sociology of Education, 45 (Spring 1972):134-66; Kenneth Prewitt, "Some Doubts About Political Socialization Research," Comparative Education Revierv, 19, no. 1 (February 1975):105-14; see also Richard Merelman's article "Social Stratification and Political Socialization in Mature Industrial Societies," Comparative Education Reviere, 19, no. 1 (February 1975).

71. M. A. Nazarova, Razvitie rechi uchashchikhsia v sviazi $s$ izucheniem russkogo sintaksisa $v$ 7-8 klassakh turkmenskoi shkoly (Ashkhabad: Turkmenskoe Gosudarstvennoe uchebno-pedagogicheskoe izdatel'stvo, 1962), pp. 3-4. 
courses continued to rise. By the late 1960s in some regions of Central Asia only a fraction of rural children were able to pass Russian language exams. In Lenin raion of Tadzhikistan, for example, only four out of sixty-one students in grades 8-10 were able to get passing marks. ${ }^{72}$

The result of the 1970 census, which clearly shows the relative lag of Central Asians in the acquisition of the Russian language, triggered more discussions on teaching methods and curriculum development. Some methods, like the one developed by a Kazakh teacher, combined formal and nonformal educational activities. Classroom instruction was supplemented by listening to radio programs in Russian and broadcasting over the local radio station in that language. Students were required to join Russian language clubs where they read newspapers printed in Russian and discussed the material with each other. Other gatherings, such as student parties and excursions, during which students spoke only Russian and gave speeches on various topics, were encouraged. In all of these activities the role of the teacher was to be that of a facilitator and a somewhat passive transmitter. ${ }^{73}$ To many people outside and inside the USSR, this method indeed looks innovative and refreshing. Unfortunately, most teachers conduct their classes in the transmitter-reciprocal method where the teacher is the sole source of knowledge and information about the language.

Another innovation was the teaching of Russian in some of the kindergartens, ${ }^{74}$ but the program of "Russian only" kindergarten is not administered uniformly in the Soviet Union. The amount of Russian hours devoted to it per year varies greatly, ranging from 10 hours of oral exercises in Kazakhstan to 840 hours in the Ukraine, Kirghizia, and Moldavia.

In 1972, A. K. Kanimetrov, the minister of education of Kirghizia, discussed the program, developed in Kirghizia and subsequently accepted by the USSR's Ministry of Education, by which children were taught Russian in kindergarten. He rationalizes the use of Russian as a means of instruction $(\mathrm{K}-10)$ despite the republic's multinationalism. After all, he says, "there were about 100 different ethnic groups in the republic in 1970 and sometimes 7-12 different nationalities in the same classroom." The only language in which instruction could be carried out, according to Kanimetrov, "was that of Russian, because this is the language in which most parents would want their children to be taught." He also goes on to say that "those who studied Russian in kinder-

72. News item, $M v M$, March 10, 1968, p. 4.

73. S. M. Chandirli, "Nasha pochta," Russkii iazyk i literatura v azerbaidzhanskoi shkole, 1972, no. 1, pp. 83-88.

74. "Vsesoiuznoe soveshchenie po nauchno-pedagogicheskim problemam obucheniia russkomu iazyku v podgotovitel'nykh klassakh," Russkii iazyk v natsional'noi shkole, 1972, no. 1, pp. 77-79. 
garten became the best students in later years and also were well adjusted."75 It is hard to know how the minister was able to establish this relationship between Russian and later achievements of these children. Nor does one know how many teachers and pupils were involved.

In all these innovations the major problem has been the type of materials selected to fit a specific age group's average ability, if not each individual child's ability. There is apparently little understanding on the part of Russian teachers about the place of abstract ideas (which some of the grammatical rules are) relative to the children's ages and intellectual development. Consequently, children are often unable to understand the basic rules of the Russian language. To make matters more complicated, a proposal has been submitted to the USSR's Ministry of Education which, if implemented, would require that Soviet literature be taught in the Russian language regardless of the mother tongues of the students studying it. ${ }^{76}$

This proposal is apparently made with little consideration of the problems that its implementation would pose. What is the purpose of non-Russians reading in Russian materials originally written in non-Russian languages? If the purpose is anything other than merely augmenting the student's stock of Russian words, it has never been articulated or demonstrated. If the proposal to teach Soviet literature (for Russian children, this means Russian literature plus a very few pieces from Western sources, but rarely anything by nonRussian Soviet writers) ${ }^{77}$ to all Soviet children in Russian is implemented, whatever is gained in Russian vocabulary is more than offset by the loss in understanding of the content of the literature, as well as the loss of aesthetic quality that often accompanies translation. More important, however, is the overwhelming evidence opposing such a policy on pedagogical grounds. ${ }^{78}$

Depending on how one views the teaching of Russian as a second language in Central Asia, the program has been either a failure or a success. It has

75. A. K. Kanimetrov, "Zaboni rusi-zaboni man, zaboni mo," TS, November 10 , 1972, p. 4.

76. K. V. Mal'tseva, "Problemhoi muhimmi ta"limi adabiyoti rus," $M v M$, April 5, 1975, p. 2.

77. See N. N. Shneidman, Literature and Ideology in Soviet Education (Toronto and London: D.C. Heath, 1973).

78. See UNESCO, Report of the Mission to Afghanistan (Paris, 1952); Cozden, "Problems for Education: Language as a Curriculum Content and Learning Environment"; A. D. Cohen, A Sociolinguistic Approach to Bilingual Education: Experiment in American Southwest (Rowley, Mass.: Newbury House, 1975); Josué Gonzalez, "Coming of Age in Bilingual/Bicultural Education: A Historical Perspective," Inequality in Education, no. 19 (February 1975), pp. 5-17; Frank M. Goodman and Carolyn Stern, Bilingual Program Evaluation Report, ESEA Title VIII, 1970-1971 (Compton, Calif.: Compton City Schools, 1971 [ED 054672]). 
been successful in making, over the past fifty years, one out of every three urbanites and one out of every ten ruralites fluent in Russian. But the TRSL program has been unsuccessful if one compares it to similar programs elsewhere in the USSR. In this comparison, the proportion of Central Asians who are fluent in Russian falls below the average of non-Russians who are fluent in the Russian language. Almost all of those who are fluent in Russian are also fluent in their mother tongues. Officially, this bilingualism is a desirable outcome of TRSL. However, this sentiment may not be similarly perceived by those who see in bilingualism a threat to the development of a genuine monolithic "Soviet culture," a culture which apparently has as a main component one language-most certainly the Russian language. These attitudes toward bilingualism have influenced the methodologies of second language pedagogy in Central Asia. As noted earlier, the practitioners of TRSL can be grouped in two general categories: those relying on "total Russian" environmentmainly the Slavs-which forbids discussions about the mother tongue; and those relying on comparative grammar-mainly indigenous Central Asianswhich requires bilingual teachers and the knowledge of the learner's culture. At present, both of these methods are used in TRSL in Central Asia. The perennial problem of scarcity of qualified Russian teachers still exists, but it is expected to be ameliorated once the vicious circle of incompetency (in which incompetent teachers train incompetent students to become incompetent teachers ad infinitum) is broken. 